CLINICAL STUDY

\title{
Co-localisation of the Kir6.2/SUR1 channel complex with glucagon-like peptide-1 and glucose-dependent insulinotrophic polypeptide expression in human ileal cells and implications for glycaemic control in new onset type 1 diabetes
}

\author{
Lotte B Nielsen, Kenneth B Ploug ${ }^{1}$, Peter Swift ${ }^{2}$, Cathrine Ørskov ${ }^{3}$, Inger Jansen-Olesen ${ }^{1}$, Francesco Chiarelli ${ }^{4}$, \\ Jens J Holst ${ }^{5}$, Philip Hougaard ${ }^{6}$, Sven Pörksen, Reinhard Holl ${ }^{7}$, Carine de Beaufort ${ }^{8}$, Steen Gammeltoft ${ }^{9}$, \\ Patrik Rorsman ${ }^{10}$, Henrik B Mortensen, Lars Hansen ${ }^{11}$ and on behalf of the Hvidøre Study Group \\ Department of Paediatrics, Glostrup University Hospital, Ndr. Ringvej 57, DK-2600 Glostrup, Denmark, ${ }^{1}$ Department of Neurology, Glostrup University \\ Hospital, Glostrup, Denmark, ${ }^{2}$ Leicester Royal Infirmary Children's Hospital, Leicester, UK, ${ }^{3}$ Department of Medical Anatomy, The Panum Institute, \\ Copenhagen, Denmark, ${ }^{4}$ Paediatric University Clinic, Chieti, Italy, ${ }^{5}$ Department of Medical Physiology, The Panum Institute, Copenhagen, Denmark, \\ ${ }^{6}$ Department of Statistics, University of Southern Denmark, Odense, Denmark, ${ }^{7}$ The University of Ulm, Ulm, Germany, ${ }^{8}$ Paediatric Clinic, \\ Luxemburg, Luxemburg, ${ }^{9}$ Department of Clinical Biochemistry, Glostrup University Hospital, Glostrup, Denmark, ${ }^{10}$ OCDEM, University of Oxford, \\ Oxford OX3 7LJ, UK and ${ }^{11}$ Development projects, Novo Nordisk A/S, Bagsveerd, Denmark \\ (Correspondence should be addressed to L B Nielsen; Email: lotbrnO1@glo.regionh.dk)
}

\begin{abstract}
Objective: The ATP-dependent $\mathrm{K}^{+}$-channel $\left(\mathrm{K}_{\mathrm{ATP}}\right)$ is critical for glucose sensing and normal glucagon and insulin secretion from pancreatic endocrine $\alpha$ - and $\beta$-cells. Gastrointestinal endocrine L- and Kcells are also glucose-sensing cells secreting glucagon-like peptide-1 (GLP-1) and glucose-dependent insulinotrophic polypeptide (GIP) respectively. The aims of this study were to 1) investigate the expression and co-localisation of the $\mathrm{K}_{\text {ATP }}$ channel subunits, Kir6.2 and SUR1, in human L- and K-cells and 2) investigate if a common hyperactive variant of the Kir6.2 subunit, Glu23Lys, exerts a functional impact on glucose-sensing tissues in vivo that may affect the overall glycaemic control in children with new-onset type 1 diabetes.

Design and methods: Western blot and immunohistochemical analyses were performed for expression and co-localisation studies. Meal-stimulated C-peptide test was carried out in 257 children at 1, 6 and 12 months after diagnosis. Genotyping for the Glu23Lys variant was by PCR-restriction fragment length polymorphism.

Results: Kir6.2 and SUR1 co-localise with GLP-1 in L-cells and with GIP in K-cells in human ileum tissue. Children with type 1 diabetes carrying the hyperactive Glu23Lys variant had higher $\mathrm{HbA}_{1 \mathrm{C}}$ at diagnosis (coefficient $=0.61 \%, P=0.02$ ) and 1 month after initial insulin therapy $($ coefficient $=0.30 \%$, $P=0.05$ ), but later disappeared. However, when adjusting $\mathrm{HbA}_{1 \mathrm{C}}$ for the given dose of exogenous insulin, the dose-adjusted $\mathrm{HbA}_{1 \mathrm{C}}$ remained higher throughout the 12 month study period (coefficient $=0.42 \%, P=0.03$ ).

Conclusions: Kir6.2 and SUR1 co-localise in the gastrointestinal endocrine L- and K-cells. The hyperactive Glu23Lys variant of the $\mathrm{K}_{\text {ATP }}$ channel subunit Kir6.2 may cause defective glucose sensing in several tissues and impaired glycaemic control in children with type 1 diabetes.
\end{abstract}

European Journal of Endocrinology 156 663-671

\section{Introduction}

The pancreatic endocrine $\alpha$ - and $\beta$-cells are glucosesensing cells equipped with an ATP-sensitive $\mathrm{K}^{+}$channel $\left(\mathrm{K}_{\text {ATP }}\right.$ channel), consisting of two subunits, SUR1 and Kir6.2. Apart from the $\alpha$ - and $\beta$-cells, the intestinal endocrine L- and K-cells are also glucosesensing tissues secreting either of the incretin hormones, glucagon-like peptide-1 (GLP-1) or glucosedependent insulinotrophic peptide (GIP), in response to glucose. The majority of K-cells are in the proximal part of the small intestine whereas the majority of L-cells are found in the distal part of the small intestine. It is assumed, from mRNA studies in a murine L-cell like cell line, GLUTag (1), that the $\mathrm{K}_{\text {АтP }}$ channel subunits are also co-expressed in L- and K-cells in vivo. The $\mathrm{K}_{\text {ATP }}$ channel subunits Kir6.2 and SUR1 have, however, not been identified at the protein level in primary human tissues from the proximal or distal gut.

Rare mutations in the Kir6.2 gene, causing various degrees of hyperactivity of the channel complex, associate with non-autoimmune diabetes syndromes including transient neonatal diabetes and permanent neonatal diabetes alone or with developmental delay 
and epilepsy (2-4). In contrast, mutations that cause loss of channel activity associate with persistent hyperinsulinaemic hypoglycaemia of infancy $(5,6)$. A common variant, Glu23Lys, of the Kir6.2 subunit (KCNJ11) was the first naturally occurring variant of Kir6.2 in vitro that was found to induce a hyperactive state of the $\mathrm{K}_{\mathrm{ATP}}$ channel complex (7) and reducing its sensitivity to the inhibitory action of ATP. In healthy subjects, the Glu23Lys variant associates with an impaired post glucose-load release of insulin $(8,9)$ and with a weaker suppression of glucagon secretion in response to hyperglycaemia (10). It has therefore been speculated that this reduction in $\beta$-cell function and increased $\alpha$-cell activity in Glu23Lys carriers may explain the association of this variant with type 2 diabetes $(8,9)$.

Although the KCNJ11 is a $\beta$-cell gene, the Glu23Lys polymorphism does not seem to increase the risk of developing type 1 diabetes (11), but its effect on disease progression and residual $\beta$-cell function in patients with newly onset type 1 diabetes has not been investigated. Type 1 diabetes is characterised by the progressive loss of insulin producing $\beta$-cells due to an autoimmune attack, and is estimated to retain $10 \%$ of the $\beta$-cell mass at the time of diagnosis (12). In parallel with the effect in impaired $\beta$-cell function $(8,9)$, the Glu23Lys variant also seems to have an effect on $\alpha$-cell function (10). But as glucagon secretion from the $\alpha$-cells may effectively be regulated by an intraislet paracrine insulin release from the $\beta$-cells, it is not possible to distinguish the effect of Glu23Lys in primary defective $\alpha$-cell function from an indirect effect caused by impaired intraislet insulin release. This influence of intraislet insulin release can better be controlled by studying newly onset type 1 diabetes with progressive loss of $\beta$-cells and, therefore, offers ideal conditions for an in vivo study of glucoseinduced glucagon secretion (13). The aims of the present study, therefore, were to 1) investigate the expression and co-localisation of the $K_{\text {ATP }}$ channel subunits, Kir6.2 and SUR1, in human small intestine (L- and K-cells); 2) investigate in vivo if a common hyperactive variant, Glu23Lys, of the Kir6.2 subunit exerts a functional impact on postprandial glucose sensing in $\alpha-, \beta-$, L- and K-cells; and 3) relate these effects to the overall glycaemic control in children with newly onset type 1 diabetes.

\section{Subjects and methods}

\section{Subjects}

This observational study was conducted in 18 centres representing 15 countries in Europe and Japan. Clinical information on demographics and anthropometry, insulin regimen as well as blood samples for centralised measurement of $\operatorname{HbA}_{1 \mathrm{c}}(0,1,3,6,9,12$ months after diagnosis) and boost-stimulated C-peptide, GLP-1, GIP and glucagon 1, 6, 12 months after diagnosis were collected prospectively. All children aged less than 16 years with newly diagnosed diabetes between August 1999 and December 2000, presenting to the paediatric departments of the participating centres, were eligible for the study. Exclusion criteria were: suspected nontype-1 diabetes (MODY, secondary diabetes etc), decline of enrolment into the study by patients or parents, and patients initially treated outside of the centres for more than 5 days. There were no significant differences with respect to gender distribution, age, anthropometric data, $\mathrm{HbA}_{1 \mathrm{c}}$ at diagnosis, ethnicity or family history of diabetes between patients included and patients not included into the study (data not shown). Only four patients from Japan were included.

The diagnosis of type 1 diabetes was according to the World Health Organisation criteria.

The cohort included 131 girls and 126 boys, 85\% of the patients were white Caucasian, age at clinical diagnosis was $9.1 \pm 3.7$ years (mean \pm s.e.M.), BMI $16.5 \pm 3.2 \mathrm{~kg} / \mathrm{m}^{2}$ (mean \pm s.e.м.) and $\mathrm{HbA}_{1 \mathrm{c}} 11.2 \pm$ $2.1 \%$ (mean \pm s.e.m.) at the time of diagnosis. Diabetic ketoacidosis was present in $20.6 \%$ of the cases at the time of diagnosis $\left(\mathrm{HCO}_{3} \leq 15 \mathrm{mmol} / \mathrm{l}\right.$ and/or $\left.\mathrm{pH}<7.30\right)$.

The study was performed according to the criteria of the Helsinki II Declaration and was approved by the local ethics committee in each centre. All patients, their parents or guardians gave informed consent.

\section{Methods: sample preparation and western blot analysis of Kir6.2, SUR1 and GLP-1 on primary human ileum tissue}

The primary antibodies used for western blot analysis were: polyclonal rabbit anti-GLP-1 code GLP2135 diluted 1:10000 (14), polyclonal goat anti-Kir6.2 code N-18 diluted 1:200 (Santa Cruz Biotechnology, Santa Cruz, CA, USA), polyclonal rabbit anti-SUR1 code H-18 diluted 1:200 (Santa Cruz Biotechnology).

The human ileum tissue sample was obtained at surgery for intestinal obstruction (male, 76 years). Pancreas and kidney were taken from a male Sprague Dawley rat anaesthetised with pentobarbital and perfused transcardially with $300 \mathrm{ml}$ ice-cold $\mathrm{Na}^{+}$Krebs buffer $(\mathrm{mM})$ : $\mathrm{NaCl} 119, \mathrm{NaHCO}_{3} 15, \mathrm{KCl} 4.6$, $\mathrm{CaCl}_{2}$ 1.5, $\mathrm{NaH}_{2} \mathrm{PO}_{4} 1.2, \mathrm{MgCl}_{2} 1.2$ and glucose 5.5 .

All tissues were immediately frozen on dry ice and stored at $-80{ }^{\circ} \mathrm{C}$ until further processing. The frozen sample was first ground on dry ice using mortar and pestle and further homogenised with a mechanical stirrer in 50-100 $\mu \mathrm{l}$ of ice-cold lysis buffer (10 mM Tris $(\mathrm{pH}=7.4), 50 \mathrm{mM} \beta$-glycerophosphate (disodium salt), $100 \mu \mathrm{M} \mathrm{Na} \mathrm{VO}_{4}, 0,5 \%$ deoxycholate, $1 \mathrm{mM}$ EGTA, $1 \mathrm{mM}$ EDTA, $1 \mathrm{mM} \mathrm{NaF}, 20 \mathrm{mM} \mathrm{Na} \mathrm{P}_{2} \mathrm{O}_{7}$ and $1 \%$ Triton X-100), containing a cocktail of protease inhibitors ( $1 \mathrm{mM}$ dithiothreitol, $20 \mu \mathrm{M}$ pepstatin, $20 \mu \mathrm{M}$ leupeptin, $0,1 \mathrm{U} / \mathrm{ml}$ aprotinin and $1 \mathrm{mM}$ phenylmethylsulphonyl fluoride). The samples were 
centrifuged at $10000 \mathrm{~g}$ for $10 \mathrm{~min}$ at $4{ }^{\circ} \mathrm{C}$ and the supernatants were collected and stored at $-80{ }^{\circ} \mathrm{C}$ until further processing.

The protein content of the samples was determined using a Bio-Rad DC protein assay (Bio-Rad). Prior to protein separation by SDS-PAGE, the protein samples were diluted $1: 1$ with a loading buffer and heated at $95^{\circ} \mathrm{C}$ for $5 \mathrm{~min}$. Each protein sample was separated in a $10 \%$ SDS-polyacrylamide gel. The separated proteins were then transferred to a PVDF membrane (Bio-Rad). The PVDF blot was blocked by $5 \%$ non-fat dry milk in Tris-buffered saline (TBS) with 1\% Tween-20 (TBS-T) for $1 \mathrm{~h}$ at room temperature. Blots were cut into half according to the expected molecular weights of the target antigens. The antibodies were diluted in TBS-T containing 3\% non-fat dry milk and the upper half was incubated with the SUR1 primary antibody and the lower half was incubated with the Kir6.2 primary antibody and the blots were left overnight at $4{ }^{\circ} \mathrm{C}$. The PVDF blots were then washed three times, 5 min each in TBS-T. The secondary antibodies, all conjugated to horseradish peroxidase, were diluted in TBS-T and incubated with the PVDF blot for $1 \mathrm{~h}$ at room temperature. The PVDF blots were then washed three times, 5 min each in TBS-T, before they were processed for analysis using an Enhanced ChemiLuminiscence detection kit (Pierce). The blots were scanned by an electronically cooled charge-coupled camera system (Fujifilm LAS-1000; Fujifilm, Tokyo 107-0052, Japan) and the chemifluorescent images were captured and stored digitally.

\section{Immunohistochemistry analysis of Kir6.2/ SUR1 and GLP-1 co-localisation on human ileum and pancreas sections}

All immunohistochemistry analysis was carried out on formalin-fixed material. Human intestinal and pancreatic tissue $(n=6)$ were obtained from archival material collected during the 1970s according to the contemporary ethical guidelines.

The antibodies used for immunohistochemistry were: monoclonal mouse anti-GLP-1 antibody code GLPb17F1A37B22C4 (F1) diluted 1:3000, generous gift from Novo Nordisk, polyclonal rabbit anti-GLP-1 antibody code GLP2135 diluted 1:10 000 (14), polyclonal rabbit anti-GIP code GIP98171 diluted 1:3000 (15), polyclonal goat anti-Kir6.2 code N-18 diluted 1:3000 (Santa Cruz Biotechnology), polyclonal goatanti SUR1 code C-16 diluted 1:1000 (Santa Cruz Biotechnology) and monoclonal mouse anti-insulin antibody code HUI 001 (Novo Nordisk, 2880 Bagsvaerd, Denmark) diluted 1:5000.

Prior to the immunohistochemical stainings the tissue sections were dewaxed and subjected to antigen retrieval by microwave irradiation in $0.5 \mathrm{mM}$ EGTA buffer $\mathrm{pH}$ 9.0.

For double labelling experiments with the antibody combination GLP-1 and Kir6.2, GLP-1 and SUR1, GIP and Kir6.2, GIP and SUR1, insulin and Kir6.2, and insulin and SUR1, the tissue sections were incubated overnight with the primary antibodies at $4{ }^{\circ} \mathrm{C}$. Bound goat antibodies were visualised using biotinylated anti goat antibody (1:200, The Binding Site), streptavidin coupled to peroxidase and biotinylated tyramide using the Perkin-Elmer TSA-indirect kit as described by the manufacturer (Perkin-Elmer) and finished by incubation with streptavidin coupled to Texas Red (Amersham). Bound mouse (F1 and HUI 001) or rabbit (98171 and 2135) antibodies were visualised using digoxigenin-coupled anti mouse/anti rabbit antibody (both 1:25, Chemicon, Billerica, MA, USA) and fluorescein-labelled anti digoxigenin antibody (1:200, Immunoresearch Laboratories, Suffolk, UK).

\section{C-peptide, glucagon, GIP and GLP-1}

Residual $\beta$-cell function (C-peptide), glucagon, GIP and GLP-1 release after a Boost-test $(6 \mathrm{ml} / \mathrm{kg}$ (max: $360 \mathrm{ml})$ of Boost/Sustacal (Mead Johnson, Evansville, IN, USA; $237 \mathrm{ml}=8 \mathrm{fl} \mathrm{oz}$ contains $33 \mathrm{~g}$ carbohydrate, $15 \mathrm{~g}$ protein and $6 \mathrm{~g}$ fat, a total of $240 \mathrm{kcal}$ ) (16) was followed 1, 6 and 12 months after diagnosis in 257 children with newly diagnosed type 1 diabetes. Blood was drawn 90 min after ingestion of the Boost drink.

Serum samples were labelled and frozen at $-20{ }^{\circ} \mathrm{C}$ until shipment on dry ice. C-peptide, glucagon, GIP and GLP-1 were analysed centrally. Samples were thawed only once for RIA determination.

Plasma C-peptide was analysed by a fluoroimmunometric assay (AutoDELFIA C-peptide. Analytical sensitivity: better than $4.97 \mathrm{pmol} / \mathrm{l} \mathrm{CV} 5 \%$ ).

Glucagon, GIP and GLP-1 concentrations in plasma were all measured after extraction of plasma with $70 \%$ ethanol (vol/vol, final concentration). The glucagon RIA was directed against the C-terminus of the glucagon molecule (antibody code no. 4305) and therefore mainly measures glucagon of pancreatic origin (17). For the GIP RIA (18) we used the C-terminal directed antiserum $\mathrm{R} 65$, which cross reacts fully with human GIP but not with the so-called GIP 8000, whose chemical nature and relationship to GIP secretion is uncertain. The antiserum reacts equally with intact GIP and GIP 3-42, the primary metabolite. Human GIP and 125-I human GIP $(70 \mathrm{MBq} / \mathrm{nmol})$ were used for standards and tracer. The plasma concentrations of GLP-1 were measured (19) against standards of synthetic GLP-1 7-36amide using antiserum code no. 89390 , which is specific for the amidated $\mathrm{C}$-terminus of GLP-1 and therefore mainly reacts with GLP-1 of the intestinal origin. The assay reacts equally with intact GLP-1 and with GLP-1 3-36amide, the primary metabolite. Because of the rapid and intravascular conversion of GLP-1 to their primary metabolites, it is essential to determine both the intact hormone and the metabolite for estimation of the rate of secretion of these hormones. For both assays, sensitivity was below 
$1 \mathrm{pmol} / \mathrm{l}$, intraassay coefficient of variation below $6 \%$ at $20 \mathrm{pmol} / \mathrm{l}$, and recovery of standard, added to plasma before extraction, about $100 \%$ when corrected for losses inherent in the plasma extraction procedure.

\section{Clinical biochemistry}

Glycaemic control as assessed by $\mathrm{HbA}_{1 \mathrm{c}}$ was determined $0,1,3,6,9$ and 12 months after diagnosis. $\mathrm{HbA}_{1 \mathrm{c}}$ was measured by ion-exchange HPLC (normal reference range 4.1-6.4\%; Steno Diabetes Centre, Gentofte, Denmark) as previously described (20).

\section{Insulin dose- adjusted $\mathrm{HbA}_{1 \mathrm{c}}$}

As $\mathrm{HbA}_{1 \mathrm{c}}$ is influenced by the insulin dose, $\mathrm{HbA}_{1 \mathrm{c}}$ and insulin dose cannot be considered separately. A unified suggestion in which both parameters were included, was found by multiple regression analysis with the logarithm of $\mathrm{C}$-peptide as the dependent variable and gender, age, $\mathrm{HbA}_{1 \mathrm{c}}$ and daily insulin dose (U/kg bodyweight) as independent variables at 1,6 and 12 months. The multiple regression analysis showed that there was a negative correlation between stimulated C-peptide and $\mathrm{HbA}_{1 \mathrm{c}}$ and insulin dose. A combined expression of insulin dose-adjusted $\mathrm{HbA}_{1 \mathrm{c}}$ was defined: actual $\mathrm{HbA}_{1 \mathrm{c}}+(4 \times$ insulin dose $(\mathrm{U} / \mathrm{Kg} / 24 \mathrm{~h}))$. A calculated dose-adjusted $\mathrm{HbA}_{1 \mathrm{c}}$ below $9 \%$ corresponded to an estimated maximal C-peptide level above $300 \mathrm{pmol} / \mathrm{l}$ and was used to define clinical remission.

\section{Genotyping}

The analysis of the Glu23Lys polymorphism of the Kir6.2 gene (KCNJ11) was performed by PCR on genomic DNA with the forward primer: 5'-GACTCTGCAGTGAGGCCCTA-3' and the reverse primer: 5'-ACGTTGCAGTTGCCTTTCTT. The PCR was carried out in a volume of $50 \mu \mathrm{l}$ containing $50 \mathrm{ng}$ genomic DNA, 1X ammoniumbuffer, $0.5 \mu \mathrm{mol} / \mathrm{l}$ of each primer, $1.0 \mathrm{mmol} / \mathrm{l}$ $\mathrm{MgCl}_{2}, 0.2 \mathrm{mmol} / \mathrm{l} \mathrm{dNTP}$ and $1 \mathrm{U}$ AmpliTaq DNA polymerase (Promega). The cycling conditions were: $3 \mathrm{~min}$ at $95^{\circ} \mathrm{C}$ followed by 35 cycles of $95^{\circ} \mathrm{C}$ for $30 \mathrm{~s}$, $60{ }^{\circ} \mathrm{C}$ for $30 \mathrm{~s}$ and $72{ }^{\circ} \mathrm{C}$ for $30 \mathrm{~s}$, with a final step at $72{ }^{\circ} \mathrm{C}$ for $9 \mathrm{~min}$. The PCR products were digested with $5 \mathrm{U}$ of BanII (New England Biolabs, Beverly, MA, USA) overnight at $37^{\circ} \mathrm{C}$, separated by gel electrophoresis on $3 \%$ NuSieve 3:1 gels (BioWhittaker Molecular Applications, Rockland, ME, USA) and finally visualised by ethidium bromide staining.

\section{Statistical methods}

Most evaluations are based on the normal distribution (GLP-1, GIP and glucagon) but C-peptide was considered on the logarithmic scale. C-peptide, $\mathrm{HbA}_{1 \mathrm{c}}$ adjusted for insulin dose, GLP-1 and glucagon values were analysed by means of multiple regression with gender, age, standard bicarbonate at onset, and the Glu23Lys variants as independent factors in a compound symmetric repeated measurement model allowing for random subject effects. A $P$ value $<0.05$ was considered statistically significant.

\section{Results}

\section{Kir6.2 and SUR1 expression and Iocalisation in primary human ileum tissue}

Western blot analysis Expression of both the poreforming and regulatory subunits of the $\mathrm{K}_{\text {ATP }}$ channel, Kir6.2 and SUR1, was found in primary tissue from human ileum (Fig. 1, lane 4, 5 and 7). The two bands for Kir6.2 detection in ileum represent one glycosylated form and one non-glycosylated form of the Kir6.2 subunit. The relatively large size for GLP-1 detection is due to the antibody recognition-site which is the large proglucagon fragment, explaining the positive signal in the pancreas sample (Fig. 1, lane 2). The relatively weak signal of the GLP-1 protein in the ileum sample is explained by the much dispersed distribution of the L-cells through the ileum tissue, as seen on Fig. 2.1b and $2.2 \mathrm{~b}$.
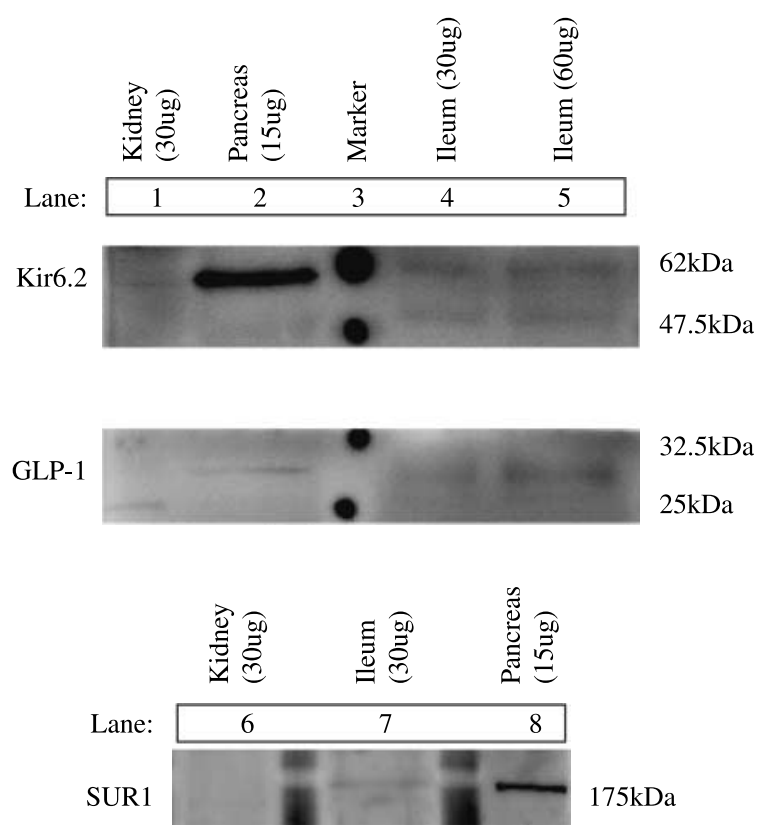

Figure 1 Western blot analysis of Kir6.2/SUR1/GLP-1 protein expression in human ileum tissue as compared with rat kidney (negative control) and rat pancreas (positive control). Molecular weights of the protein marker bands are shown to the right of the images. 


\section{Immunohistochemical analysis}

GLP1/Kir6.2/SUR1 Antibody staining demonstrated that the Kir6.2/SUR1 complex co-localised with the GLP-1-expressing cells (L-cells) in the distal part of the small intestine (Fig. 2.1 a-c and 2.2a-c).

GIP/Kir6.2/SUR1 Antibody staining demonstrated that the Kir6.2/SUR1 complex co-localised with the
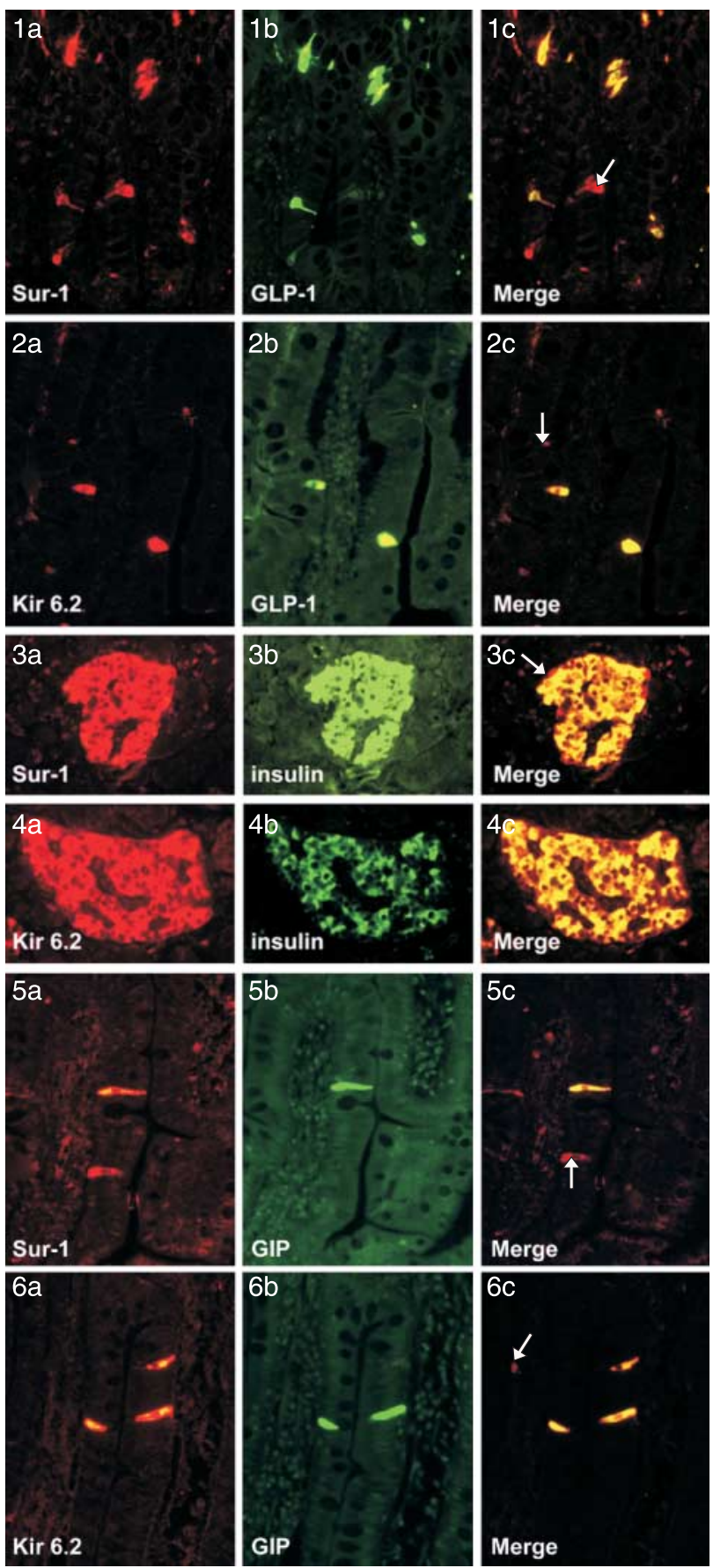

GIP-expressing cells (K-cells) in the proximal part of the gut (Fig. 2.5a-c and 2.6a-c).

Pancreas/Kir6.2/SUR1 The $\alpha$-cells and the $\beta$-cells in the pancreas exhibited Kir6.2/SUR1 staining co-localising with glucagon (the GLP-1 antibody also recognises proglucagon expression, data not shown) and insulin (Fig. 2.3a-c and 2.4a-c). The $\beta$-cells did not recognise the proglucagon antibody, emphasising the specificity of the antibodies (data not shown). The insulin negative but Kir6.2/SUR1 positive cells (colouring red) in the periphery of the islets correspond to Kir 6.2/SUR $1 \alpha$-cells (Fig. 2.3c and 2.4c).

\section{In vivo study of the functional impact of the Glu23Lys variant on $\alpha-, \beta$-, $L$ - and $K$-cells}

Genotyping The Lys allele frequency was $32.1 \%$ and the genotype frequencies of Glu23Glu, Glu23Lys and Lys23Lys were 46, 44 and 10\% respectively (Table 1). The genotypes were in Hardy-Weinberg equilibrium.

Kir6.2 genotype and residual $\beta$-cell function Mean boost-stimulated C-peptide concentrations decreased throughout the study period (1-12 months), but the Glu23Lys variant had no effect on the residual $\beta$-cell function (Fig. 3).

Kir6.2 genotype and postprandial GLP-1, GIP and glucagon release Mean Boost-stimulated GLP-1 and glucagon concentrations increased during the first 12 months after diagnosis of type 1 diabetes (Figs 4 and 5). Carriers of the Glu23Lys and Lys23Lys variants showed a weak trend for lower meal-stimulated GLP-1 release than

Figure 2 Immunohistochemical staining of Kir6.2 and SUR1 subunits in the human gut. Figure 2.1 distal part of human small intestine (a) SUR1 antibody stains red, (b) GLP-1 antibody stains green, (c) merged picture, yellow staining shows co-expression of SUR1 and GLP-1 in human L-cells, arrow indicates cell only stained for SUR1 antibody. Figure 2.2 distal part of human small intestine (a) Kir6.2 antibody stains red, (b) GLP-1 antibody stains green, (c) merged picture, yellow staining shows co-expression of Kir6. 2 and GLP-1 in human L-cells, arrow indicates cell only stained for Kir6.2 antibody. Figure 2.3 human pancreatic islets (a) SUR1 antibody stains red, (b) insulin antibody stains green, (c) merged picture, yellow staining shows co-expression of SUR1 and insulin in human $\beta$-cells, arrow indicates $\alpha$-cell only stained for SUR1 antibody.

Figure 2.4 human pancreatic islets (a) Kir6.2 antibody stains red, (b) insulin antibody stains green, (c) merged picture, yellow staining shows co-expression of Kir6.2 and insulin in human $\beta$-cells. Figure 2.5 proximal part of human small intestine (a) SUR1 antibody stains red, (b) GIP antibody stains green, (c) merged picture, yellow staining shows co-expression of SUR1 and GIP in human K-cells, arrow indicates cell only stained for SUR1 antibody. Figure 2.6 proximal part of human small intestine (a) Kir6.2 antibody stains red, (b) GIP antibody stains green, (c) merged picture, yellow staining shows co-expression of Kir6.2 and GIP in human K-cells, arrow indicates cell only stained for Kir6. 2 antibody. $200 \times$ magnification. 
Table 1 Age, gender, height, weight and genotype frequencies of the Glu23Lys variant on the Kir6.2 gene.

\begin{tabular}{lccc}
\hline & Glu23Glu & Glu23Lys & Lys23Lys \\
\hline Number & $118(46 \%)$ & $113(44 \%)$ & $26(10 \%)$ \\
Age (years) & $9.4( \pm 0.3)$ & $9.0( \pm 0.4)$ & $8.6( \pm 0.8)$ \\
Gender (M/F) & $59 / 59$ & $52 / 61$ & $15 / 11$ \\
Height $(\mathrm{cm})$ & $137( \pm 2)$ & $133( \pm 2)$ & $137( \pm 6)$ \\
Weight $(\mathrm{kg})$ & $33.6( \pm 1.5)$ & $30.4( \pm 1.2)$ & $30.6( \pm 3.2)$ \\
\hline
\end{tabular}

Values are presented as means \pm S.E.M.

carriers of the Glu23Glu genotype $(2.60 \mathrm{pmol} / \mathrm{l}$ reduction, $P=0.12$, dominant model, Fig. 4), whereas the homozygous carriers of the Lys23Lys variant tended to have higher meal-stimulated glucagon release than patients carrying the Glu23Glu and Glu23Lys genotypes ( $1.76 \mathrm{pmol} / \mathrm{l}$ reduction, $P=0.07$, recessive model, Fig. 5); neither of these analyses reach statistical significance. The GIP concentration increased during the study period, but there was no trend of association with the Glu23Lys variant $(P=0.81$, Fig. 6$)$.

\section{Impact of the Glu23Lys variant on the overall glycaemic control in patients with newly onset type} 1 diabetes Patients carrying the Glu23Lys and Lys23Lys genotypes (dominant model) had significantly higher $\mathrm{HbA}_{1 \mathrm{c}}(0.61 \%, P=0.02)$ at time of diagnosis compared with the Glu23Glu. This effect of 23Lys on $\mathrm{HbA}_{1 \mathrm{c}}\left(\mathrm{HbA}_{1 \mathrm{c}}\right.$ reflects glycaemic control 4-6 weeks before actual value) was still evident 1 month after diagnosis (coefficient $=0.30 \%, P=0.05$ ) but disappeared 3, 6, 9 and 12 months after diagnosis. When we adjusted (linear model) for the individual insulin doses, the effect reappeared and the 23Lys carriers had again higher insulin dose-adjusted $\mathrm{HbA}_{1 \mathrm{C}}$ (coefficient $=0.42 \%, P=0.03$ ) throughout the whole study period (adjusted for age, BMI and gender; Fig. 7).

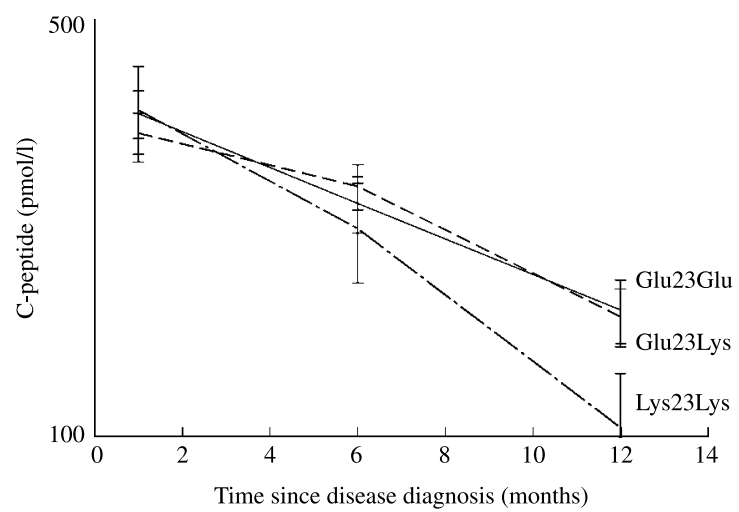

Figure 3 Meal-stimulated C-peptide (pmol/l, arithmetic means \pm S.E.M.) 12 months after diagnosis distributed according to genotypes of the Glu23Lys variant on the Kir6.2 gene, Glu23Glu, Glu23Lys and Lys23Lys.

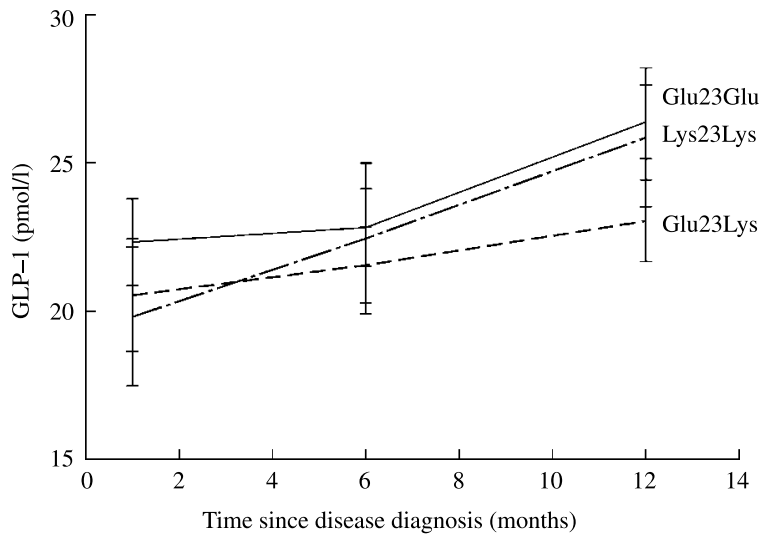

Figure 4 GLP-1 secretion (pmol/l, arithmetic means \pm S.E.M.) 12 months after diagnosis according to genotypes of the Glu23Lys variant on the Kir6.2 gene, Glu23Glu, Glu23Lys and Lys23Lys.

The poorer glycaemic control could not be explained by lower daily insulin dose (Fig. 8) as the Kir6.2 genotype did not associate with daily dose of exogenous insulin $(\mathrm{U} / \mathrm{kg} / 24 \mathrm{~h})$.

\section{Discussion}

In pancreatic $\beta$-cells, $K_{\text {ATP }}$ channels are critical in regulating normal glucose-stimulated insulin secretion (21) and the same channels are present in $\alpha$-cells where they are involved in glucagon secretion (22). The localisation of the $\mathrm{K}_{\text {ATP }}$ channel subunits, Kir6.2 and SUR1, to the gastrointestinal endocrine L- and K-cells indeed suggests that the GLP-1 and GIP secretion from these cells is regulated through the same glucosesensing machinery as is present in the $\alpha$ - and $\beta$-cells. Another site of glucose-sensing activity related to the gastrointestinal tract is the so-called hepatoportal glucose sensor (23-25). Although the specific cells of this sensor have not been identified, the glucose-sensing characteristics depend on the expression of GLUT2,

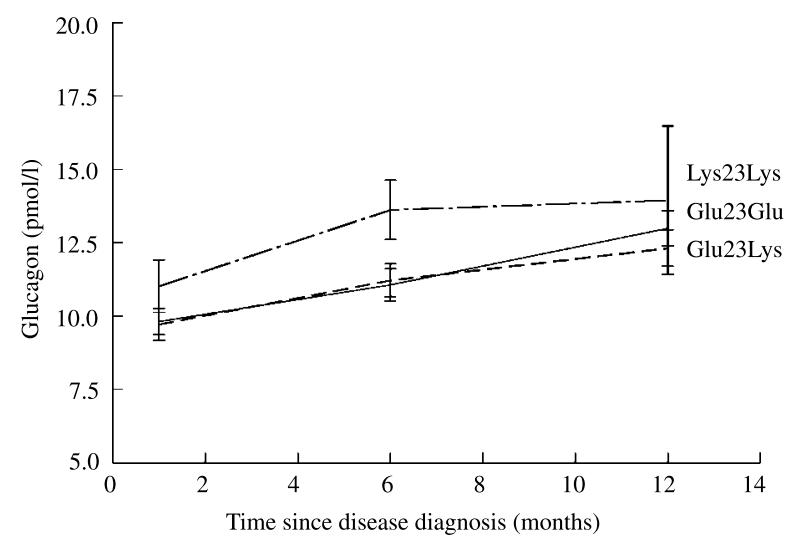

Figure 5 Glucagon secretion (pmol/l, arithmetic means \pm s.E.M.) 12 months after diagnosis according to genotypes of the Glu23Lys variant on the Kir6.2 gene, Glu23Glu, Glu23Lys and Lys23Lys. 


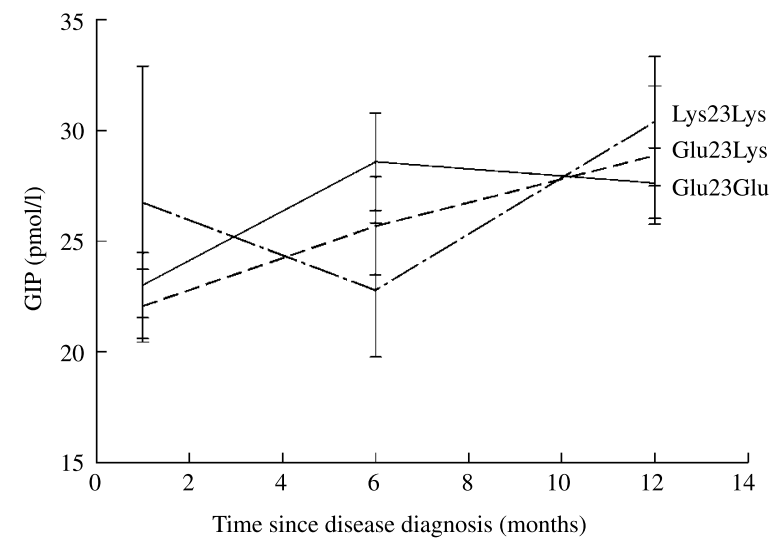

Figure 6 GIP secretion (pmol/l, arithmetic means \pm s.E.M.) 12 months after diagnosis according to genotypes of the Glu23Lys variant on the Kir6.2 gene, Glu23Glu, Glu23Lys and Lys23Lys.

glucokinase, GLP-1 receptor activity and afferent Kir6.2/SUR1 expressing glucose-sensing enteric neurons (26). The effect of the hepatoportal glucose sensor is to initiate an insulin-independent glucose uptake in skeletal muscle when portal glucose load increases (23). This insulin-independent mechanism of glucose clearance would be predicted to depend on a normal function of the Kir6.2/SUR1 complex, and consequently a hyperactive Kir6.2, like the 23Lys variant investigated in our study, would be predicted to reduce the activity of the hepatoportal sensor, to reduce the peripheral glucose uptake and impair glycaemic control.

Indeed, we found that, during insulin deficiency (acute diagnosis of type 1 diabetes), carriers of the 23Lys variant of Kir6.2 had higher $\mathrm{HbA}_{1 \mathrm{c}}$ at diagnosis and after 1 month, possibly secondary to an impaired hepatoportal glucose sensing. During exogenous insulin supplementation the negative effect of the 23Lys variant is compensated, as the difference in $\mathrm{HbA}_{1 \mathrm{c}}$ disappears after 3, 6, 9 and 12 months. However, when the glycaemic efficacy of the exogenous insulin is accounted

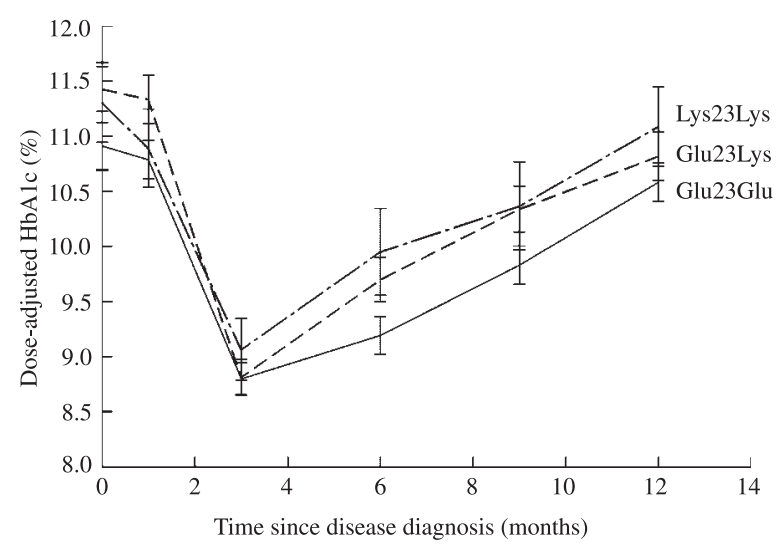

Figure 7 Insulin dose-adjusted $\mathrm{HbA}_{1 \mathrm{c}}$ (\%, arithmetic means \pm S.E.M.) 12 months after diagnosis according to genotypes of the Glu23Lys variant on the Kir6.2 gene, Glu23Glu, Glu23Lys and Lys23Lys. $P=0.03$.

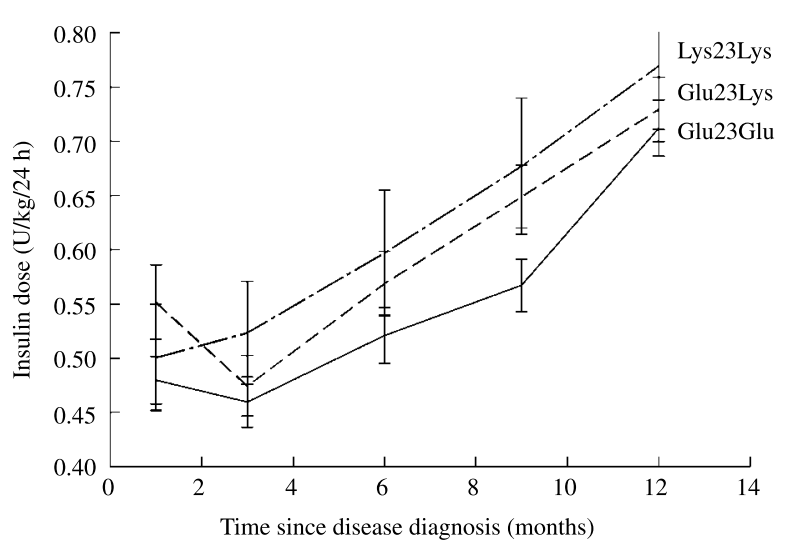

Figure 8 Insulin dose (U/kg per 24 h, arithmetic means \pm S.E.M.) 12 months after diagnosis according to genotype of the Glu23Lys variant on the Kir6.2 gene, Glu23Glu, Glu23Lys and Lys23Lys.

for, by adjusting the $\mathrm{HbA}_{1 \mathrm{c}}$ for the insulin dose, the negative effect of the 23Lys reappears and is again associated with higher insulin-dose $\mathrm{HbA}_{1 \mathrm{c}}$ and now throughout the whole study period. In subjects with sufficient/significant $\beta$-cell function the negative effect of the 23Lys on the hepatoportal glucose sensor will be difficult to visualise as it will be compensated by the endogenous insulin production, and it requires difficult and invasive procedures to estimate the endogenous insulin production on a $24 \mathrm{~h}$ basis. However, a reduction in hepatoportal glucose sensing and impaired insulin-independent peripheral glucose uptake will exert a stress to the $\beta$-cells in addition to peripheral insulin resistance, so reduced hepatoportal glucose sensing may also contribute to the association of the 23Lys variant of Kir6.2 with type 2 diabetes (8-10).

We also looked for direct evidence of a more mechanistic effect for the 23Lys variant in glucosesensing cells (other than $\beta$-cells) like the glucagonproducing $\alpha$-cells and the GLP-1/GIP producing intestinal L- and K-cells, because the residual $\beta$-cell mass in type 1 diabetes is likely too small to reveal the effect of the 23Lys variant on insulin secretion. It has previously been demonstrated in vivo that homozygous Lys23Lys hyperactive $K_{\text {ATP }}$ channels carriers have increased glucagon release during a hyperglycaemic clamp compared with heterozygous and wild type carriers (10). We could not directly confirm this finding, although we found that the homozygous carriers of the Lys23Lys showed a trend in the same direction with a $10 \%$ elevation of postprandial glucagon levels $(P=0.07)$. Similarly, we could not confirm a dominant negative effect of the 23Lys allele previously reported on glucose-induced insulin secretion (8), despite GLP-1 and GIP secretion being regulated through the same glucose-sensing machinery as is present in $\beta$-cells. Again, we merely found a weak trend of $2.6 \mathrm{pmol} / \mathrm{l}$ lower meal-stimulated GLP-1 level in 23Lys carriers $(P=0.12)$, but not the same trend with regard to the GIP levels. This could, however, be explained by the late time point for blood sampling $(90 \mathrm{~min}$ after 
Boost intake) in our study, which is more sensitive for estimating GLP-1 rather than GIP release as the GIPsecreting K-cells reside in the proximal part of the small intestine, whereas the GLP-1 secreting L-cells occupy the distal part.

The present study is the first, to our knowledge, to investigate the co-expression of Kir6.2 with GLP-1 in human tissue and the relationship in vivo between a common hyperactive $\mathrm{K}_{\mathrm{ATP}}$ channel (Lys allele), glycaemic control and meal-stimulated GLP-1 and glucagon release in patients with insulin-treated diabetes. Postprandial GLP-1 release was recently studied in five children with rare hyperactive Kir6.2 mutations before and after start of oral antidiabetic treatment with sulfonylureas, and also here GLP-1 release appeared to be unaffected (27).

Although only trends, we cannot, however, exclude that higher postprandial glucagon and lower GLP-1 levels in 23Lys carriers do not add-on to an already reduced hepatoportal glucose sensor and further impair systemic glucose regulation. An additional central (neuronal) mechanism could also contribute to elevated glucagon level among the patients homozygous for the Glu23Lys variant, as studies in Kir6.2 $2^{-/}$mice show that $\mathrm{K}_{\mathrm{ATP}}$ channels in the hypothalamus are important for glucose sensing and the activation of the $K_{\text {ATP }}$ channels is critical for glucagon secretion and food intake when the brain glucose level falls (28). Finally, lower GLP-1 levels may lead to a more rapid gastric emptying rate in the Glu23Lys carriers and result in increased postprandial glucose excursions.

Our data show that the L- and K-cells are equipped with the same $K_{\text {ATP }}$ channel complex as $\alpha$ - and $\beta$-cells indicating shared glucose-sensing regulatory machinery for these cell types in humans. The association of the 23Lys allele of the Kir6.2 with impaired glycaemic control in type 1 diabetes may suggest that a hepatoportal glucose sensor exists also in humans and need to be replicated in other prospective studies of glycaemic control in type 1 diabetes patients.

\section{Acknowledgements}

We thank Novo Nordisk for support throughout this study, with special thanks to Lene Kaa Meier and Stanislav Smirnov. We are also grateful to the technicians Oda Troest at the Department of Clinical Biochemistry, Glostrup University Hospital, and Britta Drangsfeldt and Susanne Kjelberg at Steno Diabetes Centre for their assistance. We thank the Danish Diabetes Association and the Danish Medical Research Council for financial support.

\section{References}

1 Reimann F \& Gribble FM. Glucose-sensing in glucagon-like peptide-1-secreting cells. Diabetes $2002512757-2763$.
2 Gloyn AL, Pearson ER, Antcliff JF, Proks P, Bruining GJ, Slingerland AS, Howard N, Srinivasan S, Silva JM, Molnes J, Edghill EL, Frayling TM, Temple IK, Mackay D, Shield JP, Sumnik Z, van Rhijn A, Wales JK, Clark P, Gorman S, Aisenberg J, Ellard S, Njolstad PR, Ashcroft FM \& Hattersley AT. Activating mutations in the gene encoding the ATP-sensitive potassium-channel subunit Kir6.2 and permanent neonatal diabetes. New England Journal of Medicine 2004350 1838-1849.

3 Sagen JV, Raeder H, Hathout E, Shehadeh N, Gudmundsson K, Baevre H, Abuelo D, Phornphutkul C, Molnes J, Bell GI, Gloyn AL, Hattersley AT, Molven A, Sovik O \& Njolstad PR. Permanent neonatal diabetes due to mutations in KCNJ11 encoding Kir6.2: patient characteristics and initial response to sulfonylurea therapy. Diabetes 200453 2713-2718.

4 Gloyn AL, Reimann F, Girard C, Edghill EL, Proks P, Pearson ER, Temple KI, Mackay DJG, Shield JPH, Freedenberg D, Noyes K, Ellard S, Ashcroft FM, Gribble FM \& Hattersley AT. Relapsing diabetes can result from moderately activating mutations in KCNJ11. Human Molecular Genetics 200514 925-934.

5 Nestorowicz A, Inagaki N, Gonoi T, Schoor KP, Wilson BA, Glaser B, Landau H, Stanley CA, Thornton PS, Seino S \& Permutt MA. A nonsense mutation in the inward rectifier potassium channel gene, Kir6.2, is associated with familial hyperinsulinism. Diabetes 199746 1743-1748.

6 Thomas P, Ye Y \& Lightner E. Mutation of the pancreatic islet inward rectifier Kir6.2 also leads to familial persistent hyperinsulinemic hypoglycemia of infancy. Human Molecular Genetics 19965 1809-1812.

7 Schwanstecher C, Meyer U \& Schwanstecher M. K(IR)6.2 polymorphism predisposes to type 2 diabetes by inducing overactivity of pancreatic beta-cell ATP-sensitive $\mathrm{K}(+)$ channels. Diabetes $200251875-879$.

8 Nielsen EM, Hansen L, Carstensen B, Echwald SM, Drivsholm T, Glumer C, Thorsteinsson B, Borch-Johnsen K, Hansen T \& Pedersen O. The E23K variant of Kir6.2 associates with impaired post-OGTT serum insulin response and increased risk of type 2 diabetes. Diabetes 200352 573-577.

9 Lyssenko V, Almgren P, Anevski D, Orho-Melander M, Sjogren M, Saloranta C, Tuomi T \& Groop L. the Botnia Study Group. Genetic prediction of future type 2 diabetes. PLoS Medicine 200512 1299-1308.

10 Tschritter O, Stumvoll M, Machicao F, Holzwarth M, Weisser M, Maerker E, Teigeler A, Haring $\mathrm{H}$ \& Fritsche A. The prevalent Glu23Lys polymorphism in the potassium inward rectifier 6.2 (KIR6.2) gene is associated with impaired glucagon suppression in response to hyperglycemia. Diabetes $2002 \mathbf{5 1} 2854-2860$.

11 Eftychi C, Howson JM, Barratt BJ, Vella A, Payne F, Smyth DJ, Twells RC, Walker NM, Rance HE, Tuomilehto-Wolf E, Tuomilehto J, Undlien DE, Ronningen KS, Guja C, IonescuTiirgoviste C, Savage DA \& Todd JA. Analysis of the type 2 diabetes-associated single nucleotide polymorphisms in the genes IRS1, KCNJ11, and PPARG2 in type 1 diabetes. Diabetes 200453 870-873.

12 Steele C, Hagopian WA, Gitelman S, Masharani U, Cavaghan M, Rother KI, Donaldson D, Harlan DM, Bluestone J \& Herold KC. Insulin secretion in type 1 diabetes. Diabetes 200453 426-433.

13 Maruyama H, Hisatomi A, Orci L, Grodsky GM \& Unger RH. Insulin within islets is a physiologic glucagon release inhibitor. Journal of Clinical Investigation 198474 2296-2299.

14 Orskov C, Holst JJ, Poulsen SS \& Kirkegaard P. Pancreatic and intestinal processing of proglucagon in man. Diabetologia 198730 874-881.

15 Mortensen K, Christensen LL, Holst JJ \& Orskov C. GLP-1 and GIP are colocalized in a subset of endocrine cells in the small intestine. Regulatory Peptides 2003114 189-196.

16 The DCCT Research Group. Effects of age, duration and treatment of insulin-dependent diabetes mellitus on residual beta-cell function: observations during eligibility testing for the diabetes control and complications trial (DCCT). Journal of Clinical Endocrinology and Metabolism 198765 30-36. 
17 Holst JJ. Evidence that enteroglucagon (II) is identical with the C-terminal sequence (residues 33-39) of glicentin. Biochemical Journal $1982 \mathbf{2 0 7} 381-388$.

18 Krarup T, Madsbad S, Moody AJ, Regeur L, Faber OK, Holst JJ \& Sestoft L. Diminished gastric inhibitory polypeptide (GIP) response to a meal in newly diagnosed type I (insulin dependent) diabetics. Journal of Clinical Endocrinology and Metabolism 1983 56 1306-1312.

19 Orskov C, Rabenhøj L, Kofod H, Wettergren A \& Holst JJ. Production and secretion of amidated and glycine-extended glucagon-like peptide-1 (GLP-1) in man. Diabetes 1994 43 535-539.

20 Nielsen LB, Mortensen HB, Chiarelli F, Holl R, Swift P, de Beaufort C, Pociot F, Hougaard P, Gammeltoft S, Knip M, Hansen L \& Hvidore Study Group, . Impact of IDDM2 on disease pathogenesis and progression in children with newly diagnosed type 1 diabetes: reduced insulin antibody titres and preserved beta cell function. Diabetologia 200649 71-74.

21 Misler S, Barnett DW, Gillis KD \& Pressel DM. Electrophysiology of stimulus-secretion coupling in human beta-cells. Diabetes 1992 41 1221-1228.

22 Gopel SO, Kanno T, Barg S, Weng XG, Gromada J \& Rorsman P. Regulation of glucagon release in mouse-cells by $\mathrm{K}_{\text {ATP }}$ channels and inactivation of TTX-sensitive $\mathrm{Na}^{+}$channels. Journal of Physiology $2000 \mathbf{5 2 8} 509-520$.

23 Burcelin R, Dolci W \& Thorens B. Portal glucose infusion in the mouse induces hypoglycemia: evidence that the hepatoportal glucose sensor stimulates glucose utilization. Diabetes $2000 \mathbf{4 9}$ 1635-1642.
24 Burcelin R, Dolci W \& Thorens B. Glucose sensing by the hepatoportal sensor is GLUT2-dependent. Diabetes $2000 \mathbf{4 9}$ 1643-1648.

25 Burcelin R, Da Costa A, Drucker D \& Thorens B. Glucose competence of the hepatoportal vein sensor requires the presence of an activated glucagon-like peptide-1 receptor. Diabetes 200150 1720-1728.

26 Liu M-T, Seino S \& Kirchgessner AL. Identification and characterization of glucoresponsive neurons in the enteric system. Journal of Neuroscience 199919 10305-10317.

27 Pearson ER, Flechtner I, Njolstad PR, Malecki MT, Flanagan SE, Larkin B, Ashcroft FM, Klimes I, Codner E, Iotova V, Slingerland AS, Shield J, Robert JJ, Holst JJ, Clark PM, Ellard S, Sovik O, Polak M, Hattersley AT \& Neonatal Diabetes International Collaborative Group, . Switching from insulin to oral sulfonylureas in patients with diabetes due to Kir6.2 mutations. New England Journal of Medicine 2006 355 467-477.

28 Miki T, Liss B, Minami K, Shiuchi T, Saraya A, Kashima Y, Horiuchi M, Ashcroft F, Minokoshi Y, Roeper J \& Seino S. ATPsensitive $\mathrm{K}^{+}$channels in the hypothalamus are essential for the maintenance of glucose homeostasis. Nature Neuroscience 20014 507-512.

Received 20 December 2006

Accepted 12 March 2007 